Eawag_06125

Limnol. Oceanogr., 55(5), 2010, 2073-2084

(C) 2010, by the American Society of Limnology and Oceanography, Inc.

doi: $10.4319 / 10.2010 .55 .5 .2073$

\title{
Hypolimnetic oxygen consumption by sediment-based reduced substances in former eutrophic lakes
}

\author{
Andreas Matzinger,a, ${ }^{*}$ Beat Müller,b,c Pius Niederhauser, ${ }^{d}$ Martin Schmid,b and Alfred Wüest ${ }^{b, c}$ \\ a Kompetenzzentrum Wasser Berlin (KWB), Berlin, Germany \\ bEawag, Surface Waters-Research and Management, Swiss Federal Institute of Aquatic Science and Technology, Kastanienbaum, \\ Switzerland \\ c Institute of Biogeochemistry and Pollutant Dynamics, Swiss Federal Institute of Technology Zurich (ETH), Zurich, Switzerland \\ dAmt für Abfall, Wasser, Energie und Luft (AWEL), Zurich, Switzerland
}

\begin{abstract}
We quantified the areal hypolimnetic mineralization rate (AHM; total areal hypolimnetic oxygen depletion including the formation of reduced substances) in two formerly eutrophic lakes based on $20 \mathrm{yr}$ of water-column data collected during oligotrophication. The upward diffusion of reduced substances originating from the decomposition of organic matter in the sediment was determined from pore-water profiles and related to the time of deposition. More than $80 \%$ of AHM was due to degradation of organic matter in the water column (including sediment surface) and diffusion of reduced substances from sediment layers younger than $10 \mathrm{yr}$. Sediments older than $10 \mathrm{yr}$, including the eutrophic past, accounted for $\sim 15 \%$ of AHM. This "old" contribution corresponds to a $20-43 \%$ fraction of the total sediment-based AHM. The contribution from old sediment layers to AHM is expected to be even lower in lakes with deeper hypolimnia $(>12 \mathrm{~m})$. In summary, oxygen consumption in stratified hypolimnia is controlled mainly by the present lake productivity. As a result, technical lake management measures, such as oxygenation, artificial mixing, or sediment dredging, cannot efficiently decrease the flux of reduced substances from the sediment.
\end{abstract}

In deep stratified lakes there is generally a clear correlation between lake productivity and areal hypolimnetic oxygen depletion rate (AHOD; $\mathrm{g} \mathrm{O}_{2} \mathrm{~m}^{-2} \mathrm{~d}^{-1}$ ), as first shown by Hutchinson (1938). Consequently, eutrophication leads to an increase in AHOD (Rast and Lee 1978; Chapra and Canale 1991) and potentially low dissolved oxygen (DO) levels in the hypolimnion during summer stratification. Low hypolimnetic DO can in turn have a serious effect on biological processes, either via direct toxicity on fish and bottom organisms (Kalff 2002) or indirectly via toxic by-products of anaerobic mineralization (Wang and Chapman 1999). Moreover, it has been shown that hypolimnetic anoxia can enhance the sediment release of soluble reactive phosphorus (P; Larsen et al. 1981; Hupfer and Lewandowski 2008), although the DO concentration at the sediment-water interface is not the only controlling factor (Moosmann et al. 2006).

As a result, reaching or maintaining a sufficient hypolimnetic DO level is often a focus of lake management. Commonly used approaches focus on (1) the reduction of external P loading (Gächter and Wehrli 1998), (2) increased DO supply to the hypolimnion through oxygenation or aeration (Singleton and Little 2006) or through artificial mixing in winter (Müller and Stadelmann 2004), or (3) the removal of accumulated deposits of organic matter through sediment dredging (Annadotter et al. 1999). However, in many lakes AHOD decreased only slowly following the reduction of external $P$ sources and the subsequent decrease in lake productivity. Such a resilience of AHOD during oligotrophication was observed in Lake Shagawa (Larsen

\footnotetext{
*Corresponding author: andreas.matzinger@ kompetenz-wasser.de
}

et al. 1981) and Lake Eire (Charlton et al. 1993). A similar effect was described by Matthews and Effler (2006) for Lake Onondaga, where an abrupt decrease in anthropogenic organic matter input coincided with a slow decline in $\mathrm{P}$ concentration in the lake. In all three cases, the observed resilience of AHOD was attributed to organic matter depositions from former eutrophic times and reduced degradation products that diffuse from the sediment into the water column.

The influence of the sediment on AHOD is supported by previous work showing that hypolimnetic accumulation of the reduced substances methane $\left(\mathrm{CH}_{4}\right)$ and ammonium $\left(\mathrm{NH}_{4}^{+}\right)$in Lake Shagawa (Carignan and Lean 1991) and of sulfide (S[-II]) and $\mathrm{CH}_{4}$ in Lake Onondaga (Gelda et al. 1995) during summer anoxia originated predominantly from the sediment. Additionally, Carignan and Lean (1991) found that the degradation of the refractory part of deposited organic matter to reduced substances could take decades to centuries. Together with the relatively slow, diffusion-controlled flux of reduced substances from the sediment (Lorke et al. 2003; Bryant et al. 2010), these results can well explain a delayed effect of sedimented organic matter on hypolimnetic DO. This sediment "memory effect" is expected to be significant, as described for Danish (Liboriussen et al. 2009) and Swiss lakes (Müller and Stadelmann 2004), where the sediment remained a major DO sink even after decades of oxygenation and/or aeration. However, although the possible sediment memory effect is established by the above examples, the contribution of older sediment layers to the present AHOD, as well as a potential decrease in the sediment flux of reduced substances with time, has not been assessed. 
Table 1. Lake characteristics.

\begin{tabular}{lcc}
\hline \hline & Pfäffikersee & Türlersee \\
\hline Lake surface area $\left(\mathrm{km}^{2}\right)^{*}$ & 3.03 & 0.50 \\
Lake cross-sectional area at $\mathrm{z}=10 \mathrm{~m}\left(\mathrm{~km}^{2}\right) \dagger$ & 2.45 & 0.33 \\
Lake volume $\left(10^{6} \mathrm{~m}^{3}\right)^{*}$ & 57.1 & 6.5 \\
Hypolimnion volume $(\mathrm{z}>10 \mathrm{~m})\left(10^{6} \mathrm{~m}^{3}\right) \dagger$ & 29.5 & 2.3 \\
Maximal depth $(\mathrm{m})^{*}$ & 35.0 & 22.0 \\
Lake outflow $\left(\mathrm{m}^{3} \mathrm{~s}^{-1}\right)^{*}$ & 0.86 & 0.11 \\
Average water residence time $(\mathrm{d})^{*}$ & 770 & 730 \\
TP concentration 1970-1989 $\left(\mathrm{mg} \mathrm{P} \mathrm{m}^{-3}\right) \ddagger$ & $140 \pm 5$ & $69 \pm 3$ \\
TP concentration 1990-1999 $\left(\mathrm{mg} \mathrm{P} \mathrm{m}^{-3}\right) \ddagger$ & $35.8 \pm 1.4$ & $20.8 \pm 0.8$ \\
TP concentration 2000-2006 $\left(\mathrm{mg} \mathrm{P} \mathrm{m}^{-3}\right) \ddagger$ & $19.5 \pm 0.5$ & $16.1 \pm 0.6$ \\
Start of artificial mixing by aeration & Winter 1992-1993 & Winter 1987-1988 \\
\hline
\end{tabular}

* From Niederhauser et al. 2006.

$\uparrow$ Based on bathymetry (AWEL unpubl. data).

$\$$ Volume-weighted average \pm SEM.

AHOD can be quantified only for aerobic hypolimnia, although the mineralization of organic matter continues with electron acceptors other than DO under anoxic conditions. During anaerobic mineralization in the sediment, reduced substances are generated and released to the water column. It is convenient to include these reductants in the DO balance and to extend the concept of AHOD; consequently, the areal hypolimnetic mineralization rate (AHM; $\mathrm{g} \mathrm{O}_{2} \mathrm{~m}^{-2} \mathrm{~d}^{-1}$ ), is used in this article. AHM includes AHOD and the oxygen equivalents that reduced substances would consume when oxidized. Thus, although AHM is equal to AHOD in the presence of sufficient DO, AHM also includes dissolved reduced substances that may be present under suboxic conditions. At steady state, AHM is equal to the total mineralization of organic matter in the hypolimnion and the sediment.

This article aims at characterizing the sediment memory effect on AHM in two formerly eutrophic lakes, Pfäffikersee (PF) and Türlersee (TU). Both lakes have reached mesotrophic levels of $\sim 20-30 \mathrm{mg} \mathrm{P} \mathrm{m}^{-3}$ in the early $1990 \mathrm{~s}$ after excessive eutrophication in the 1970s with $\sim 100$ $350 \mathrm{mg} \mathrm{P} \mathrm{m}{ }^{-3}$. Despite $\mathrm{P}$ load reduction and artificial mixing in winter, the hypolimnia in these lakes still become anoxic during summer stratification. Therefore, the two lakes make ideal sites for studying the sediment release from the eutrophic past.

We base our analysis on more than $20 \mathrm{yr}$ of monthly measurements of DO and major reduced substances in the water column of both lakes. The excellent data set allowed AHM to be quantified for the stratified period each year, despite annual anoxia. For both lakes, AHM was compared to sediment fluxes calculated from sediment pore-water profiles obtained in the 1990s and in 2007. Because sediment cores were dated and sedimentation rates were determined, the sediment contribution could also be related to the time of deposition.

In summary, our analysis focuses on answering the following three questions relevant for lake management: (1) What is the contribution of reduced, sediment-based substances from a eutrophic past to present AHM? (2) How long will older sediment layers contribute to the present AHM? (3) Are artificial measures, such as oxygenation or sediment dredging, effective in lowering or shortening the effect of the past?

\section{Methods}

Study sites-PF and TU are small glacial lakes situated on the Swiss Plateau (Table 1). Despite their relatively shallow average depths of $13 \mathrm{~m}$ (TU) and $19 \mathrm{~m}$ (PF), they are subject to strong temperature-induced density stratification in summer. In the 1970s and 1980s PF underwent complete convective mixing approximately every second winter. In other winters only partial deep destratification occurred, as shown clearly in Fig. 1a by the profiles from spring 1982. TU remained permanently chemically stratified throughout the same period (as shown by spring 1982 data in Fig. 1c).

The long-term $\mathrm{P}$ development shown in Fig. 2 demonstrates that both lakes were subject to intense eutrophication from 1960 to 1980 when high primary productivity led to permanent anoxia in the hypolimnion of $\mathrm{TU}$ and seasonal anoxia each summer in PF (Fig. 3). Eutrophication was also seen as the major cause of chemical stratification of the hypolimnetic water column.

Naturally occurring convective mixing in winter has been enhanced in both lakes by artificial air-bubble plumes since 1987 (TU) and 1992 (PF). Applying artificial mixing in winter prevents the reestablishment of chemical stratification and ensures high DO concentrations at the onset of thermal stratification in spring. The destratification systems are run between November and March, successfully maintaining complete destratification throughout the winter season (Figs. 1b,d, 3).

Sampling and analyses-The study is based on long-term water quality monitoring by the Canton of Zurich (Switzerland). For the monitoring program, water samples were collected monthly along depth profiles at the deepest sites at intervals of $2.5-5 \mathrm{~m}$. Samples were analyzed for DO, $\mathrm{NH}_{4}^{+}$, and nitrite $\left(\mathrm{NO}_{2}^{-}\right)$using standard analytical methods (DEW 2002). S(-II) and $\mathrm{CH}_{4}$ were measured using photometry and gas chromatography, respectively (DEW 2002). 

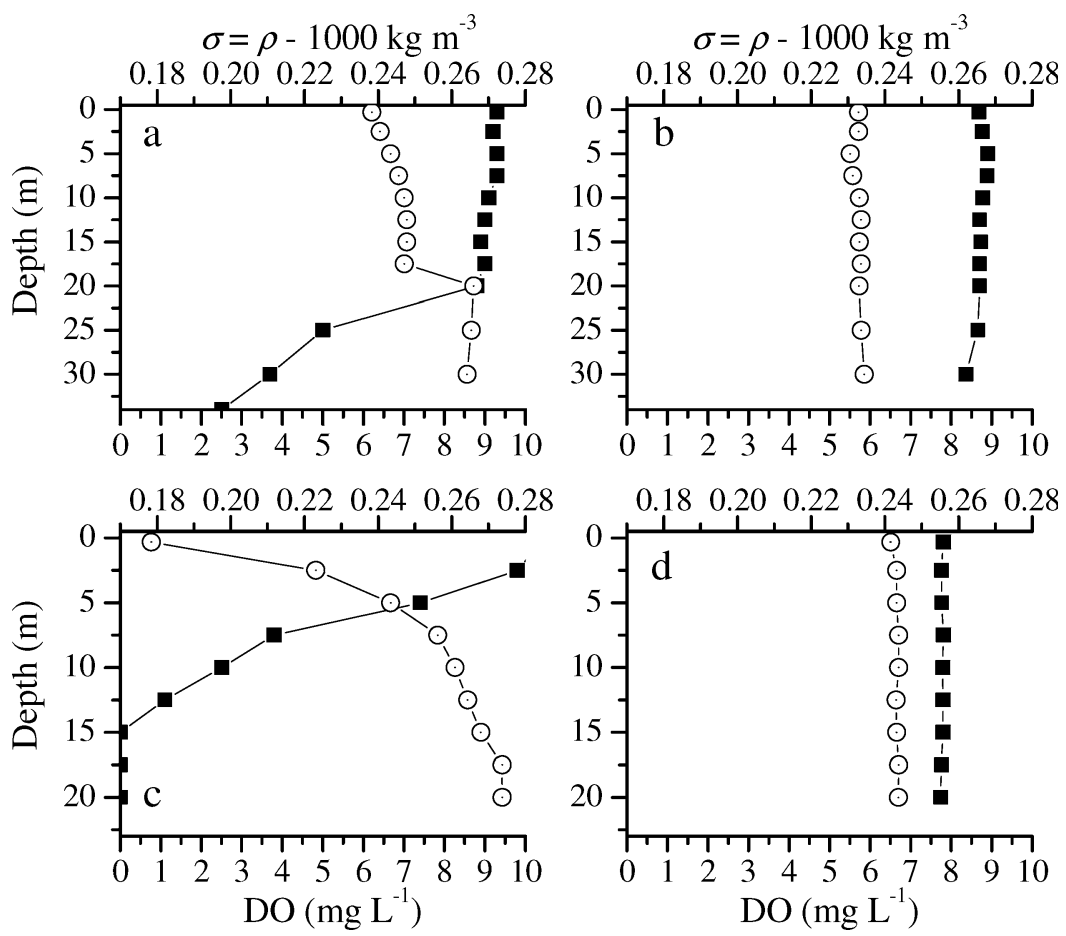

Fig. 1. Typical profiles of DO (squares) and water density (circles) at the onset of spring stratification before (exemplified by 1982, left column) and since (exemplified by 2006, right column) artificial mixing in winter. (a) PF, 23 March 1982; (b) PF, 28 March 2006; (c) TU, 02 April 1982; (d) TU, 29 March 2006.

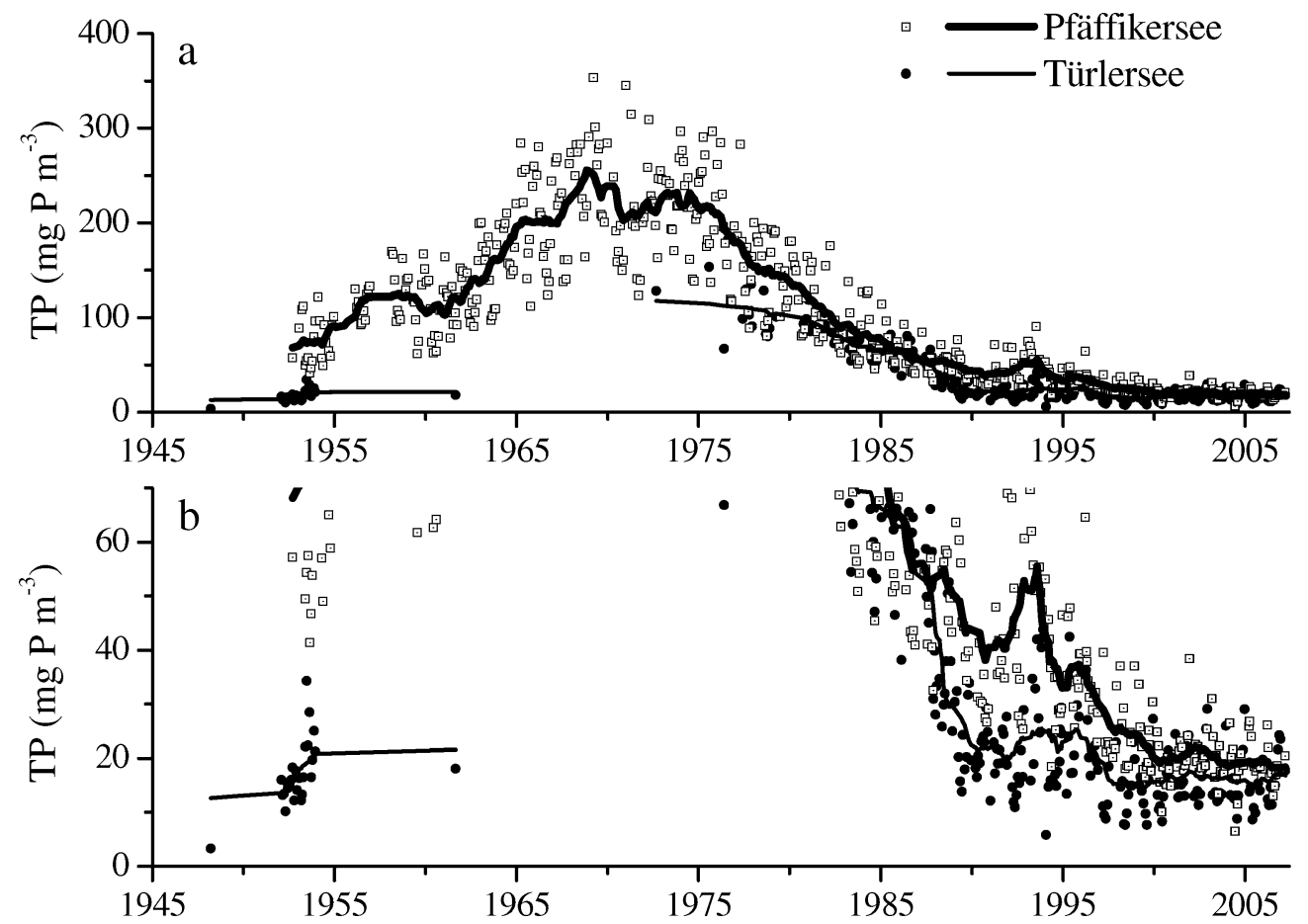

Fig. 2. (a) Temporal development of volume-averaged TP in PF (squares) and TU (circles). Lines are 20-point running averages. No measurements for TU between 1961 and 1972. (b) Same data with higher resolution. 
Eawag_06125
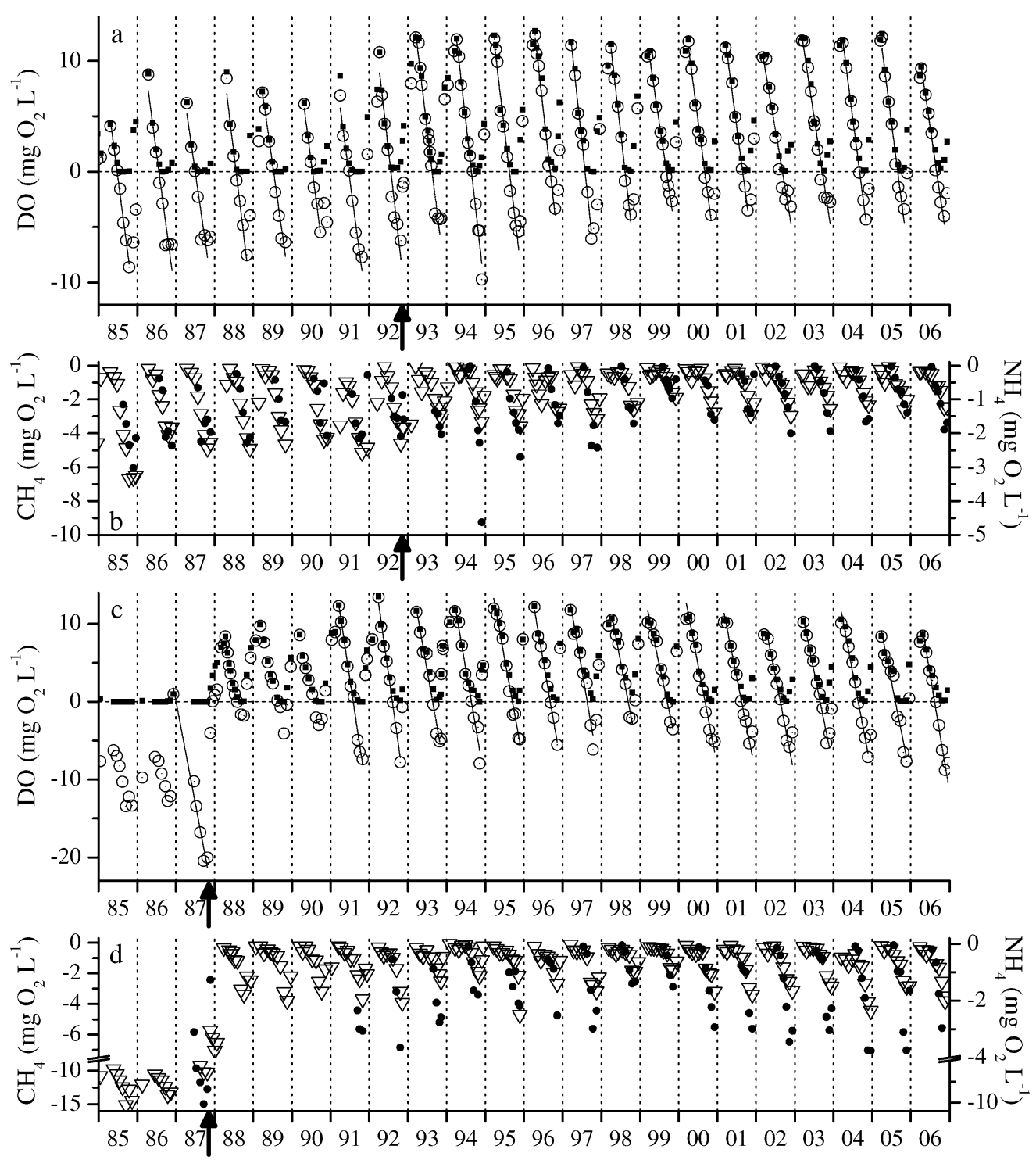

Fig. 3. Measured DO (squares) and calculated $\mathrm{DO}_{\text {equiv }}$ (circles) concentrations in the hypolimnia of (a) PF and (c) TU from 1985 to 2006. $\mathrm{DO}_{\text {equiv }}$ is calculated following Eq. 1. Fine lines are linear regressions, used to estimate AHM. For summers without regression line, $\mathrm{CH}_{4}$ was not measured and $\mathrm{DO}_{\text {equiv }}$ is overestimated. Measured concentrations of $\mathrm{NH}_{4}^{+}$(triangles) and $\mathrm{CH}_{4}(\mathrm{circles})$ are shown in $\mathrm{O}_{2}$ equivalents for the hypolimnia of (b) PF and (d) TU. Note the axis break in (d). The arrows indicate onset of artificial mixing by aeration during winter.

Sediment cores were collected on 26 April 2007 at a depth of $32 \mathrm{~m}$ in $\mathrm{PF}$ and at $21 \mathrm{~m}$ in TU using a gravity corer. On the boat immediately following core retrieval, a $\mathrm{CH}_{4}$ sample of the overlying core water was drawn with a tube into a $100-\mathrm{mL}$ serum flask, a few $\mathrm{NaOH}$ pellets were added, and the bottle was sealed with a septum to eliminate air bubbles. Pore-water samples for $\mathrm{CH}_{4}$ analysis were also obtained immediately. For pore-water sampling, holes of $1.2-\mathrm{cm}$ diameter had been drilled (and covered with tape) in the polyvinyl chloride core tube $(6.5-\mathrm{cm}$ diameter), in $1-\mathrm{cm}$ vertical intervals. After core retrieval the tape was cut open over each hole and a subcore was extracted with a syringe (top cut off). The subcore (2-mL volume) was extruded into a $25-\mathrm{mL}$ serum bottle containing $4 \mathrm{~mL}$ of $2.5 \% \mathrm{NaOH}$ and then sealed with a septum. $\mathrm{CH}_{4}$ was later analyzed in the headspace by gas chromatography with a Sepak-packed column and flame ionization detection.

Samples for the other reduced substances were taken on a second core. Overlying water was sampled directly after cores were retrieved using a plastic tube; care was taken not to disturb the core prior to sealing for further analyses. Pore-water samples were collected the following day by gentle vacuum filtration of $0.5-\mathrm{cm}$ vertical sections in the top $10 \mathrm{~cm}$ of the sediment cores. Water samples were analyzed photometrically for $\mathrm{NH}_{4}^{+}$and $\mathrm{S}(-\mathrm{II})$. For measurements of reduced iron ( $\mathrm{Fe}[\mathrm{II}])$, and manganese $(\mathrm{Mn}[\mathrm{II}])$, samples were acidified with concentrated nitric acid (suprapure) and analyzed using inductively coupled plasma spectroscopy with optical emission (ICP-OES, Spectro Ciros, Spectro Analytik). The 1-d period between 
Table 2. Oxygen equivalents and molecular diffusivities of reduced substances.

\begin{tabular}{lcc}
\hline \hline $\begin{array}{c}\text { Reduced } \\
\text { substance } \mathrm{S}\end{array}$ & $\begin{array}{c}\mathrm{O}_{2} \text { equivalents } \\
\left(\mathrm{mol} \mathrm{O}_{2}\right)(\mathrm{mol} \mathrm{S})^{-1 *}\end{array}$ & $\begin{array}{c}\text { Molecular diffusivity } \\
\left(\times 10^{-9} \mathrm{~m}^{2} \mathrm{~s}^{-1}\right) \dagger\end{array}$ \\
\hline $\mathrm{CH}_{4}$ & 2 & 0.92 \\
$\mathrm{Fe}(\mathrm{II})$ & 0.25 & 0.41 \\
$\mathrm{~S}(-\mathrm{II})$ & 2 & 1.15 \\
$\mathrm{Mn}(\mathrm{II})$ & 0.5 & 0.37 \\
$\mathrm{NH}_{4}^{+}$ & 2 & 1.18 \\
$\mathrm{NO}_{2}^{-}$ & 0.5 & -+ \\
\hline
\end{tabular}

* From Stumm and Morgan 1996.

$\uparrow$ At $4^{\circ} \mathrm{C}$ and zero salinity, from Li and Gregory 1974.

$\$ \mathrm{No} \mathrm{NO}_{2}^{-}$flux calculated.

core retrieval and sampling may have resulted in a slight underestimation of pore-water concentrations of reduced substances $\mathrm{NH}_{4}^{+}, \mathrm{S}(-\mathrm{II}), \mathrm{Fe}(\mathrm{II})$ and $\mathrm{Mn}(\mathrm{II})$ in the top $1 \mathrm{~cm}$ of the core at the maximum.

Pore-water data from 2007 were compared with earlier pore-water data obtained with in situ diffusion plate samplers (DPS) placed in the sediment at $21.5 \mathrm{~m}$ depth on 22 December 1994 in TU by Aeberli and Keller (1995), and at $30 \mathrm{~m}$ depth on 25 March 1992, 05 April 1993, 07 April 1994, and 04 April 1995 in PF by Niederhauser (1995). The DPS used for these studies consisted of 60-cm-long Perspex plates of $1-\mathrm{cm}$ thickness. Holes were drilled with a vertical resolution of $2.5 \mathrm{~cm}$, filled with distilled water, and sealed on both sides with $0.45-\mu \mathrm{m}$ membrane filters. The DPS were left in the sediment for $14 \mathrm{~d}$ to allow for equilibration of ion concentrations between the pore water and the distilled water in the DPS. The plate was then retrieved and the water in the cavities sampled and analyzed.

Varve counts and identification of the 1962-1963 and $1986{ }^{137}$ Cs peaks by Elber et al. $(2001 a, b)$ resulted in average sedimentation rates of $0.4 \mathrm{~cm} \mathrm{yr}^{-1}$ (PF) and $0.5 \mathrm{~cm} \mathrm{yr}^{-1}$ (TU) for the top 2 and $7 \mathrm{~cm}$ of the cores, respectively, and $0.3 \mathrm{~cm} \mathrm{yr}^{-1}$ for both lakes below the top layer.

Equivalent oxygen concentration -If DO concentration decreases below a certain threshold, alternative electron acceptors are used by microorganisms to mineralize organic matter, which in turn leads to the production of reduced substances, such as $\mathrm{NH}_{4}^{+}, \mathrm{S}(-\mathrm{II})$, or $\mathrm{CH}_{4}$ (Stumm and Morgan 1996). If DO increases again, e.g., as a result of convective winter mixing, reduced substances become oxidized and DO is consumed. Because we are interested in the total potential DO consumption, we convert fluxes of reduced substances into equivalent DO fluxes (Gelda et al. 1995). In terms of concentration, we use the equivalent DO concentration in the water column ( $\left.\mathrm{DO}_{\text {equiv }}\right)$ as follows (Table 2):

$$
\begin{aligned}
{\left[\mathrm{DO}_{\text {equiv }}\right]=} & {[\mathrm{DO}]-0.5\left[\mathrm{NO}_{2}^{-}\right]-2\left[\mathrm{NH}_{4}^{+}\right] } \\
& -2[\mathrm{~S}(-\mathrm{II})]-2\left[\mathrm{CH}_{4}\right]
\end{aligned}
$$

where brackets indicate molar concentrations (DO in mol $\left.\mathrm{O}_{2} \mathrm{~m}^{-3}\right) . \mathrm{Fe}(\mathrm{II})$ and $\mathrm{Mn}(\mathrm{II})$ are omitted in Eq. 1, because they were not measured in the water column. However, measurements in the sediment pore water indicate that their contribution is only in the range of $\sim 1 \%$ and is therefore negligible for PF and TU (Table 3). Per Eq. 1, DO equiv is negative if reduced substances prevail.

Flux calculation-AHM is calculated as the average rate of depletion of in situ $\mathrm{DO}_{\text {equiv }}$ in the hypolimnion (Fig. 3). The calculation is identical to AHOD (Matthews and Effler 2006) except that $\mathrm{DO}$ is replaced with $\mathrm{DO}_{\text {equiv. }}$ In this study, $\mathrm{DO}_{\text {equiv }}$ was determined with Eq. 1 for each of the monthly profiles, based on DO and reduced substances, and volume-averaged over the hypolimnion below 10-m depth. Finally, AHM was calculated annually for the observed depletion of $\mathrm{DO}_{\text {equiv }}$ during summer stratification

Table 3. Oxygen fluxes $\left(\mathrm{g} \mathrm{O}_{2} \mathrm{~m}^{-2} \mathrm{~d}^{-1}\right){ }^{1992-1995}$ vs. 2004-2007.

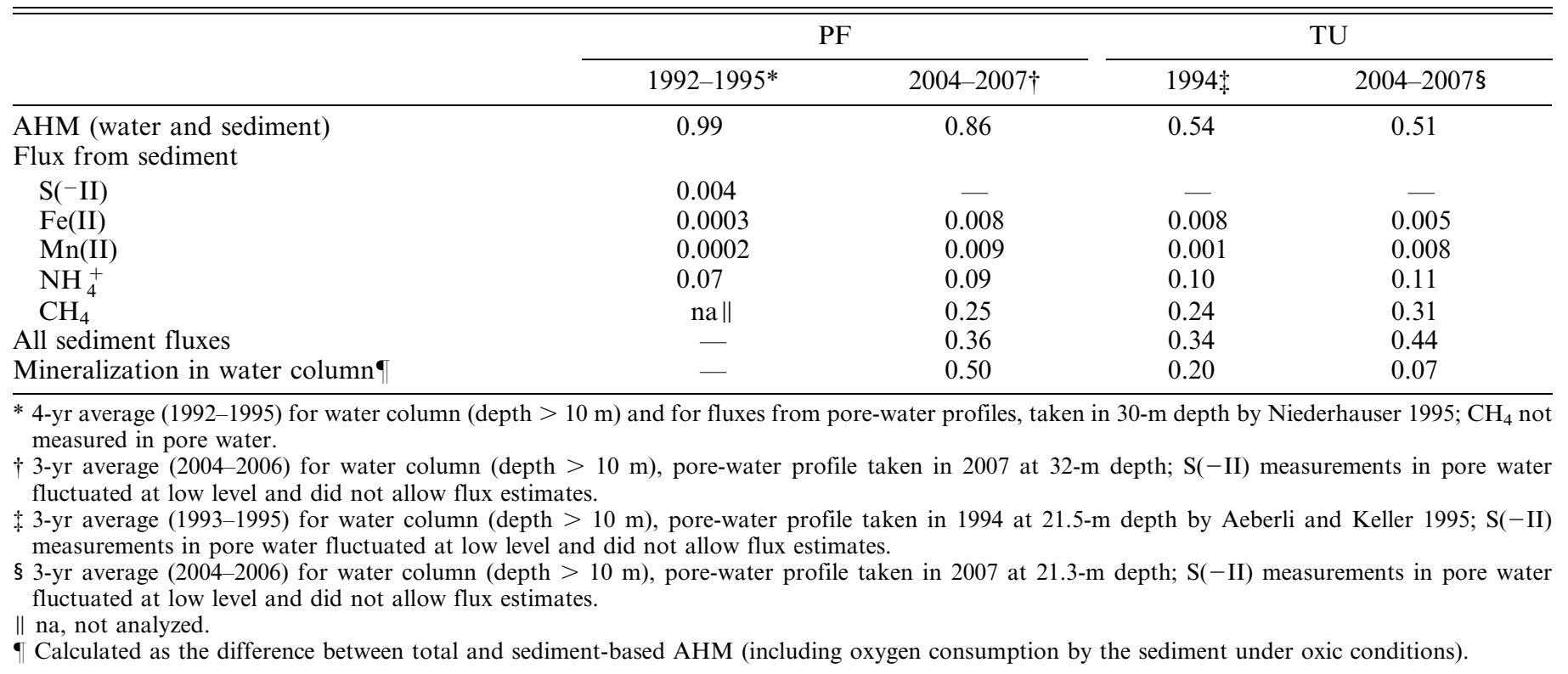


using linear regression (Fig. 3). Confidence intervals of linear regression were used as error estimates of AHM. Because there is a downward DO flux from the epilimnion to the hypolimnion via turbulent diffusion, the AHM calculation underestimates mineralization. We have estimated downward DO fluxes based on temperature development in the epilimnion and hypolimnion for each year using the method by Chapra (1997), as suggested by Matthews and Effler (2006) for AHOD correction.

Fluxes of reduced substances across the sediment-water interface were calculated from sediment pore-water concentration profiles using the one-dimensional second Fickian law balancing production and consumption of a substance in the sediment, as well as molecular diffusion along concentration gradients. We applied the two-layer approach (Model 4) by Epping and Helder (1997), as outlined in Müller et al. (2006). The approach distinguishes between fast and slowly degradable organic matter with the volumetric degradation rates $\mathrm{R}_{1}$ and $\mathrm{R}_{2}$, respectively. The sediment is split into two layers with volumetric degradation rates $R_{1}+R_{2}$ in fresh and $R_{2}$ in older sediment:

$$
\begin{aligned}
& \mathrm{z}_{1}>\mathrm{z}>0: \\
& \mathrm{C}(\mathrm{z})=\frac{\Phi \cdot \mathrm{F}}{2 \mathrm{D}_{0}} \cdot\left(\mathrm{R}_{1}+\mathrm{R}_{2}\right) \cdot \mathrm{z}^{2}-\frac{\Phi \cdot \mathrm{F}}{\mathrm{D}_{0}} \cdot\left(\mathrm{R}_{1} \cdot \mathrm{z}_{1}+\mathrm{R}_{2} \cdot \mathrm{Z}_{\max }\right) \cdot \mathrm{z}+\mathrm{C}_{0} \\
& \mathrm{Z}_{\max }>\mathrm{z}>\mathrm{z}_{1}: \\
& \mathrm{C}(\mathrm{z})=\frac{\Phi \cdot \mathrm{F}}{2 \mathrm{D}_{0}} \cdot \mathrm{R}_{2} \cdot \mathrm{z}^{2}-\frac{\Phi \cdot \mathrm{F}}{\mathrm{D}_{0}} \cdot \mathrm{R}_{2} \cdot \mathrm{z}_{\max } \cdot \mathrm{z}-\frac{\Phi \cdot \mathrm{F}}{2 \mathrm{D}_{0}} \cdot \mathrm{R}_{1} \cdot \mathrm{z}_{1}{ }^{2}+\mathrm{C}_{0}
\end{aligned}
$$

where $\mathrm{C}\left(\mathrm{mol} \mathrm{m} \mathrm{m}^{-3}\right)$ is concentration, $\mathrm{z}(\mathrm{m})$ is sediment depth, $\Phi=0.9$ is porosity, $\mathrm{F}=\left(\right.$ tortuosity $\left.^{2} \times \Phi^{-1}\right)=1.23$ is the formation factor according to Maerki et al. (2004), $\mathrm{D}_{0}\left(\mathrm{~m}^{2} \mathrm{~s}^{-1}\right)$ is the compound-specific molecular diffusivity (Table 2), and $\mathrm{R}_{1}$ and $\mathrm{R}_{2}\left(\mathrm{~mol} \mathrm{~m}^{-3} \mathrm{~s}^{-1}\right)$ are fast and slow volumetric degradation rates, respectively. The depth of the top sediment layer $\left(\mathrm{z}_{1}\right)$ as well as the reaction rates $\mathrm{R}_{1}$ and $R_{2}$ were fitted visually to meet the measured pore-water profiles optimally. Parameters were fitted separately for each profile and compound because the structure of porewater profiles depends on compound-specific local transformation rates, molecular diffusivity, and net sedimentation, as well as other factors not accounted for by the simplified two-layer approach. However, $z_{1}$ is typically similar for different reduced substances on the same date. Based on the approximations (Eq. 2), fluxes of reduced substances $\mathbf{J}\left(\mathrm{mol} \mathrm{m}^{-2} \mathrm{~s}^{-1}\right)$ can be calculated with the first Fickian law using diffusion coefficients in Table 2 and the formation factor by Maerki et al. (2004):

$$
\mathrm{J}=-\frac{\mathrm{D}_{0}}{\mathrm{~F}} \cdot \frac{\mathrm{dC}(\mathrm{z})}{\mathrm{dz}}
$$

Equation 3 allows quantification of fluxes across the sediment-water interface or across any given sediment depth z. dC/dz was calculated by differentiating fitted Eq. 2. As a result the flux at the sediment-water interface can be calculated as $\mathrm{J}(\mathrm{z}=0)=\Phi \times\left(\mathrm{R}_{1} \times \mathrm{z}_{1}+\mathrm{R}_{2} \times \mathrm{z}_{\max }\right)$. It is important to note that $\mathrm{J}(\mathrm{z}=0)$ is subject to uncertainties from (1) possible underestimation of concentrations of reduced substances in the top $1 \mathrm{~cm}$ (see above), (2) approximations of Eq. 2 to different resolutions and depths of pore-water profiles from 2007 and from the 1990s (see above), and (3) generally ambiguous definition of the interface between sediment and water column (concerning the top few millimeters of sediment). Nevertheless, fluxes between $\sim 1$ and $10 \mathrm{~cm}$ (corresponding to $\sim 2$ and $\sim 24$ $30 \mathrm{yr}$ ) are expected to be robust.

\section{Results}

Total AHM-Initially, observed AHM from linear regression (Fig. 3) was compared to downward DO fluxes from the epilimnion. As a result of strong stratification in both lakes, the contribution of downward DO fluxes to AHM was found to be small (7\% in TU and $8 \%$ in PF), clearly below the estimated error of observed AHM $(95 \%$ confidence interval of linear regression, $16 \%$ in $\mathrm{TU}$ and $13 \%$ in PF). Moreover, downward DO fluxes were relatively constant over the observed period (SD $\sim 20 \%$ for both lakes) and therefore the correction would not change the temporal pattern of AHM. Consequently, we did not consider the DO flux from the epilimnion in AHM in the following analyses, unless stated otherwise.

Figure 3 indicates that the mineralization rate was independent of DO concentration. As a result, AHM is directly comparable to AHOD (if only the linear part is used for the latter). When artificial mixing in winter was maintained via aeration system operations, total seasonal hypolimnetic reduction in $\mathrm{DO}_{\text {equiv }}$ ( $=\mathrm{AHM} \times$ duration of summer stratification) was dominated by actual DO depletion (PF, 69\%; TU, 57\%) with the remainder resulting from an accumulation of reduced substances (Fig. 3). This accumulation (in $\mathrm{O}_{2}$ equivalents) was dominated in turn by $\mathrm{CH}_{4}$ (PF, 71\%; TU, 76\%), followed by $\mathrm{NH}_{4}^{+}$(PF, 26\%; $\mathrm{TU}, 22 \%), \mathrm{NO}_{2}^{-}$(PF, 2.3\%; TU, 0.5\%), and $\mathrm{S}(-\mathrm{II})(\mathrm{PF}$, $0.7 \%$; TU, $1.6 \%$ ). Prior to artificial mixing (before 1988 or 1993; Fig. 3), DO depletion contributed less (PF, 50\%; TU, $0 \%$ ) given the lower DO concentration at the onset of summer stratification. Contributions to reduced substance accumulation also differed; $\mathrm{CH}_{4}$ still dominated, though to a lesser extent (PF, 57\%; TU, 65\%), followed by $\mathrm{NH}_{4}^{+}(\mathrm{PF}$, $33 \%$; TU, 29\%), S(-II) (PF, 8\%; TU, 6\%), and $\mathrm{NO}_{2}^{-}$(PF, $2 \%$; TU, $0.03 \%$ ). In both lakes, artificial mixing in winter increased the fraction of DO depletion of AHM and reduced the contributions of $\mathrm{NH}_{4}^{+}$and particularly $\mathrm{S}(-\mathrm{II})$ to accumulation of reduced substances.

The DO deficit is distinctly lower today than in the 1980 s, which is indicated by less negative $\mathrm{DO}_{\text {equiv }}$ minima in both lakes (Fig. 3). In TU, this reduction is clearly the result of artificial mixing in winter, because the hypolimnion remained permanently stratified and anoxic before 1987 (Fig. 3b). For PF, no immediate effect of artificial winter mixing is apparent in $\mathrm{DO}_{\text {equiv }}$ (Fig. 3a).

Regarding AHM, artificial mixing resulted in a small increase from $0.88 \pm 0.07 \mathrm{~g} \mathrm{O}_{2} \mathrm{~m}^{-2} \mathrm{~d}^{-1}$ (1985-1992) to $1.01 \pm 0.04 \mathrm{~g} \mathrm{O}_{2} \mathrm{~m}^{-2} \mathrm{~d}^{-1}$ (1993-1998) in PF (Fig. 4). This increase was followed by a reduction in AHM from summer 1998 to summer 1999 to $0.82 \pm 0.07 \mathrm{~g} \mathrm{O}_{2} \mathrm{~m}^{-2} \mathrm{~d}^{-1}$ 


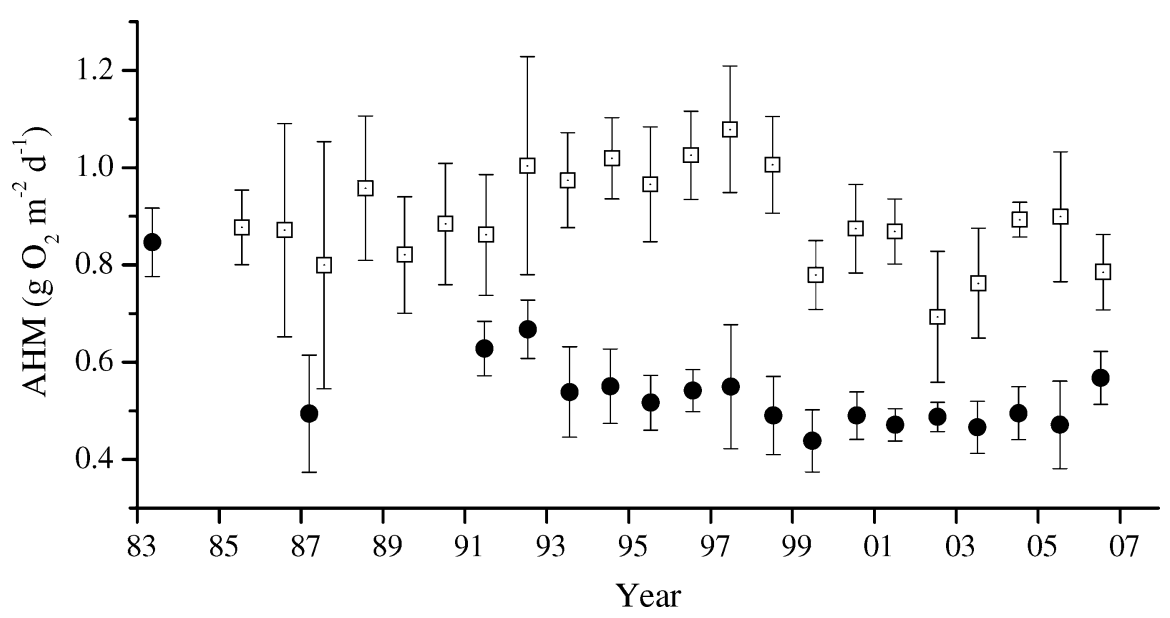

Fig. 4. AHM during summer stratification (expressed in $\mathrm{O}_{2}$ equivalents) in the hypolimnion $(\mathrm{z}>10 \mathrm{~m}$ ) from 1983 to 2006 for PF (squares) and TU (circles). Error bars indicate 95\% confidence intervals for flux estimates from linear regression (Fig. 3).

(1999-2006). For TU, AHM decreased significantly ( $p$ value $=0.002$ for the null hypothesis that the slope equals zero) over the observation period. If only values after the onset of artificial mixing are considered (excluding 1983 and 1987), the decrease is weaker but still significant ( $p=$ 0.009).

In conclusion, no distinct immediate reduction in AHM was observed in either of the lakes as a result of artificial mixing in winter. Contrarily, AHM initially increased slightly for a few years after the onset of artificial mixing in PF. Regarding long-term effects, interpretation is difficult because total P (TP) concentrations in both lakes have decreased further over the observation period. Fig. 5 shows AHM vs. winter TP (average TP in the epilimnion during the preceding winter). In PF, winter TP concentration for the first $5 \mathrm{yr}$ of artificial mixing (1993-1997) was $57 \pm 14 \mathrm{mg} \mathrm{P} \mathrm{m}^{-3}$, distinctly higher than $\sim 30 \pm 6 \mathrm{mg} \mathrm{P} \mathrm{m}^{-3}$ after 1997. This decrease in TP may explain the drop in AHM in Fig. 4. If only the period with active artificial mixing (1993-2006) is considered, there is a significant $(p=$ 0.025 ) decrease in AHM with decreasing TP. For TU, AHM was $\sim 60 \%$ higher at 2.3 -fold TP concentration in 1983 compared to AHM and TP after 1987, leading to a significant correlation between TP and AHM. After the

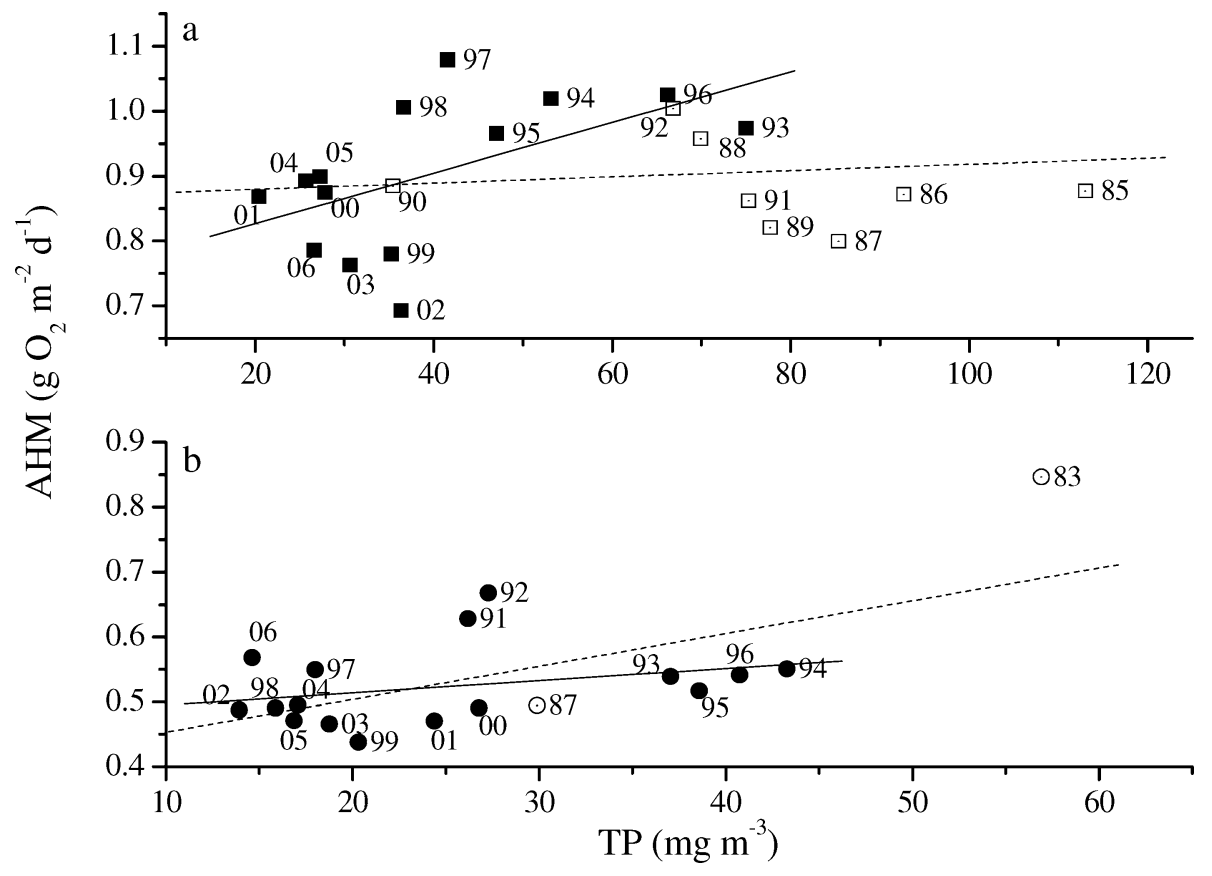

Fig. 5. AHM during summer stratification as a function of TP (at end of winter mixing) for (a) PF and (b) TU. Numbers indicate year of observation. Dotted lines are linear regressions for full data set; solid lines are linear regressions for measurements after the onset of artificial mixing in winter (indicated by filled symbols). 

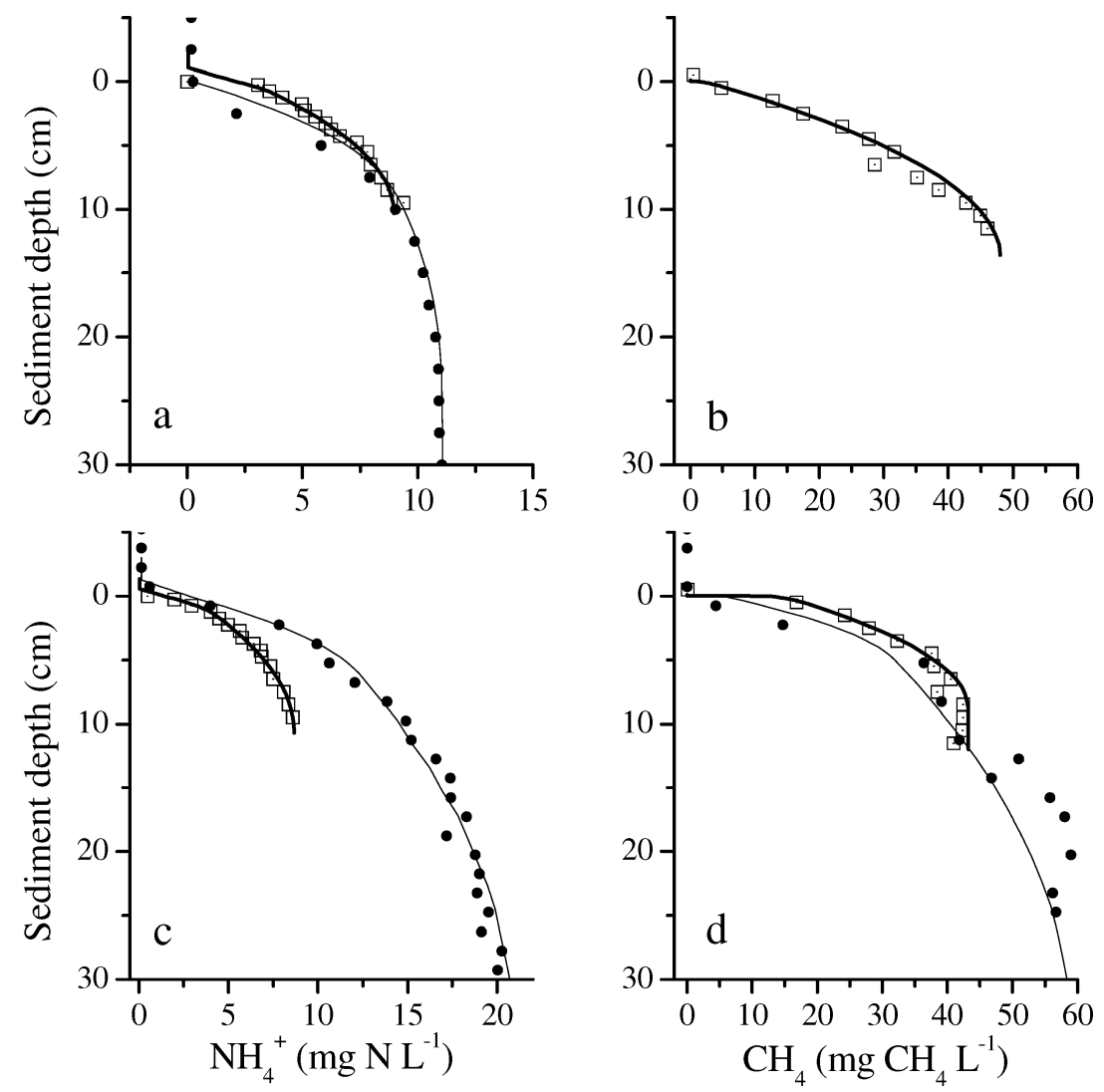

Fig. 6. Pore-water profiles for $\mathrm{NH}_{4}^{+}$and $\mathrm{CH}_{4}$ from the 1990s (circles, fine lines) and 2007 (squares, bold lines) in (a,b) PF and (c,d) TU. Lines represent fitted approximations, used for flux calculations. For the 1990s cores, averages of four pore-water profiles from 1992 to 1995 are shown for PF (Niederhauser 1995) and profiles from 1994 are shown for TU (Aeberli and Keller 1995).

onset of artificial mixing (between 1991 and 2006) the TP range in $\mathrm{TU}$ was much smaller than in $\mathrm{PF}$ and no significant TP-AHM correlation was found $(p=0.27)$.

Fluxes of reduced substances from sediment-Table 3 lists fluxes of reduced substances at the sediment-water interface in $\mathrm{O}_{2}$ equivalents. In general, results show similar areal contributions between 0.34 and $0.44 \mathrm{~g} \mathrm{O}_{2} \mathrm{~m}^{-2} \mathrm{~d}^{-1}$ in both lakes. $\mathrm{CH}_{4}$ contributes around $70 \%$ to total sediment fluxes, followed by $\mathrm{NH}_{4}^{+}$with $25-29 \%$, in close agreement with the contributions of these substances to AHM. Fluxes of other reduced substances $\mathrm{Mn}(\mathrm{II}), \mathrm{Fe}(\mathrm{II})$ and $\mathrm{S}(-\mathrm{II})$ are more than one order of magnitude smaller.

Although pore-water profiles were sampled with different methods in the 1990s and 2007 (see above), results compare well. Figure 6 shows pore-water profiles for the dominant reduced substances, $\mathrm{NH}_{4}^{+}$and $\mathrm{CH}_{4}$, with approximations fitted to the data. $\mathrm{In} \mathrm{PF}, \mathrm{NH}_{4}^{+}$profiles and fluxes show no major difference between the early 1990s and today (Fig. 6a; Table 3). In TU, $\mathrm{NH}_{4}^{+}$ concentrations decreased markedly in the deeper sediment between 1994 and 2007 (Fig. 6c) whereas change in the $\mathrm{CH}_{4}$ profiles was negligible (Fig. 6d). Nevertheless, $\mathrm{NH}_{4}^{+}$ fluxes at the sediment surface remained constant, with a slight increase in $\mathrm{CH}_{4}$ flux (Table 3). The contribution of reduced substances from the sediment interior to the observed AHM is $\sim 42 \%$ for PF and between 63\% (1994) and 86\% (2006-2007) for TU (Table 4). If downward DO fluxes from the epilimnion are included, the contribution of sediment-based AHM is in the same range but slightly smaller, with $\sim 39 \%$ for PF and between $59 \%$ (1994) and 79\% (2006-2007) for TU.

Table 4. Contribution of water column and different sediment layers to AHM.

\begin{tabular}{|c|c|c|c|}
\hline & \multicolumn{3}{|c|}{$\%$ of $\mathrm{AHM}$} \\
\hline & \multirow{2}{*}{$\frac{\mathrm{PF}}{2004-2007}$} & \multicolumn{2}{|r|}{ TU } \\
\hline & & 1994 & 2004-2007 \\
\hline Mineralization in water column & 58 & 37 & 14 \\
\hline All sediment fluxes & 42 & 63 & 86 \\
\hline $\begin{array}{l}\text { Reduced substances from } \\
\text { sediment layers with time of } \\
\text { deposition }\end{array}$ & & & \\
\hline $0-2$ yr ago & 18 & 10 & 47 \\
\hline $2-5$ yr ago & 4 & 14 & 11 \\
\hline $5-10$ yr ago & 3 & 23 & 11 \\
\hline $10-20$ yr ago & 6 & 4 & 16 \\
\hline $\begin{array}{l}>20 \text { yr ago (includes time of } \\
\text { major eutrophication) }\end{array}$ & 12 & 12 & 1 \\
\hline
\end{tabular}


Table 5. Estimation of necessary phosphorus reduction in PF and TU in order to reach the goals of $\mathrm{DO}>0$ and $>4 \mathrm{mg} \mathrm{L}^{-1}$.

\begin{tabular}{|c|c|c|}
\hline & $\mathrm{PF}$ & TU \\
\hline Gross annual $\mathrm{P}$ sedimentation $\mathrm{P}_{\text {sed }}\left(10^{3} \mathrm{~kg} \mathrm{P} \mathrm{yr}^{-1}\right)^{*}$ & 2.0 & 0.2 \\
\hline Hypolimnetic DO needed for degradation of sedimented organic matter $\left(\mathrm{mg} \mathrm{O}_{2} \mathrm{~L}^{-1}\right) \dagger$ & 10 & 12 \\
\hline Available DO at onset of summer stratification $\left(\mathrm{mg} \mathrm{O}_{2} \mathrm{~L}^{-1}\right)$ & 10 & 10 \\
\hline TP goal for $\mathrm{DO}>0 \mathrm{mg} \mathrm{O}_{2} \mathrm{~L}^{-1}\left(\mathrm{mg} \mathrm{P} \mathrm{m}^{-3}\right) \ddagger$ & 20 & 13 \\
\hline Necessary reduction in $\mathrm{P}$ input $(\%) \S$ & 0 & 19 \\
\hline TP goal for $\mathrm{DO}>4 \mathrm{mg} \mathrm{O}_{2} \mathrm{~L}^{-1}\left(\mathrm{mg} \mathrm{P} \mathrm{m}^{-3}\right) \ddagger$ & 12 & 8 \\
\hline Necessary reduction in $\mathrm{P}$ input $(\%) \S$ & 40 & 50 \\
\hline
\end{tabular}

* AWEL unpubl. data.

$\uparrow$ Assuming Redfield stoichiometry.

* Assuming constant ratio between TP and $\mathrm{P}_{\text {sed }}$.

$\S$ Using P model by Vollenweider 1969.

Contribution from the eutrophic past - Based on the porewater profile approximations in Fig. 6, the flux contribution from dated sediment layers can be calculated. In all pore-water profiles, more than $50 \%$ of total sediment-based AHM was attributed to material that had settled in the previous $10 \mathrm{yr}$ (Table 4). For current pore-water profiles (2007), sediment layers deposited during the eutrophication period (1960-1980; Fig. 2) have a comparably small effect of $12 \%$ and $1 \%$ on AHM for PF and TU, respectively (Table 4). Sediments deposited less than 2 yr ago were found to make the highest contribution. The relatively low contribution of older sediment layers was confirmed by a first-order exponential decay approximation to the porewater profiles (AHM contribution of sediment layers $>$ $20 \mathrm{yr}, 10 \%$ in PF and 3\% in TU), which emphasizes the robustness of the results. The overall distribution between sediments $<10 \mathrm{yr}$ and $>10 \mathrm{yr}$ is similar for the 1994 porewater profile in TU; however, annual layers $<10 \mathrm{yr}$ are distributed more equally than for the 2007 profiles (Table 4).

\section{Discussion}

AHM approach - The calculation of $\mathrm{DO}_{\text {equiv }}$ allows the assessment of DO deficits in hypolimnia of stratified lakes. More than $20 \mathrm{yr}$ of measurements in PF and TU show that depletion of $\mathrm{DO}_{\text {equiv }}$ (i.e., $\mathrm{AHM}$ ) is directly comparable to AHOD, but can also be used to estimate mineralization under anoxic conditions. Similar results have been reported for other aerated lakes as well (Scheidegger et al. 1994). Overall, $\mathrm{DO}_{\text {equiv }}$ and AHM are robust conceptual parameters for the assessment of DO deficits and the effectiveness of mitigation measures for stratified lakes with periods of anoxia.

AHM progression-AHM remained surprisingly constant throughout the observation period at $\sim 0.90 \pm$ $0.10 \mathrm{~g} \mathrm{O}_{2} \mathrm{~m}^{-2} \mathrm{~d}^{-1}(1985-2006)$ and $\sim 0.54 \pm$ $0.10 \mathrm{~g} \mathrm{O}_{2} \mathrm{~m}^{-2} \mathrm{~d}^{-1}$ (1983-2006) in PF and TU, respectively. The values are within the expected range of AHOD for natural lakes of these TP levels (Rast and Lee 1978; Chapra and Canale 1991). Observed hypolimnetic accumulation of reduced substances was dominated by $\mathrm{CH}_{4}(57-76 \%)$ and $\mathrm{NH}_{4}^{+}(22-29 \%)$. These contributions compare well to results by Bédard and Knowles (1991) who found $70 \%$ and
$24 \%$ contribution of $\mathrm{CH}_{4}$ and $\mathrm{NH}_{4}^{+}$, respectively, in Lake St. George.

As a result of artificial mixing in winter and the subsequent higher hypolimnetic DO at the onset of summer stratification, the contribution of DO depletion to total AHM clearly increased in both lakes. Furthermore, the relative contributions of $\mathrm{NH}_{4}^{+}$and $\mathrm{S}(-\mathrm{II})$ decreased whereas those of $\mathrm{CH}_{4}$ increased; however, no reduction in AHM was observed. Conversely, AHM increased in PF after the onset of artificial mixing. A similar increase of AHM after aeration has been frequently observed in lakes and is usually attributed to enhanced mixing (Gantzer et al. 2009).

AHM dependence on P-Correlation between TP concentration and AHM emphasizes the controlling influence of current lake productivity on AHM (Fig. 5).

If recurring anoxia during summer stratification in $\mathrm{PF}$ and $\mathrm{TU}$ is the result of current lake productivity, TP concentrations would have to be further reduced to avoid anoxia in the hypolimnion. Based on an existing $\mathrm{P}$ balance for the lakes (Amt für Abfall, Wasser, Energie, und Luft Zurich [AWEL] unpubl. data), we estimated the DO concentration required at the onset of summer stratification (Table 5) in order to mineralize the annually sedimented organic matter (assuming Redfield stoichiometry and a constant ratio between TP and sedimented organic matter). The analysis shows that PF is almost at the TP level, where the newly settled organic matter could be degraded by the available DO without accumulation of reduced substances; however, further $\mathrm{P}$ reduction would be necessary for $\mathrm{TU}$. The calculations also indicate that persisting anoxia can be explained by the current trophic state of the two lakes alone (and no past depositions need to be included).

To put PF and TU observations into perspective, we compared their TP-AHM relationships to published data for other temperate lakes. Figure 7a shows that both lakes are similar to other European and North American lakes (AHM for lakes 1-5, AHOD for lakes 6-8 with oxic hypolimnia). TP-AHM pairs in PF lie above the empirical relationship for AHOD by Chapra and Canale (1991) after the onset of artificial mixing in winter (Fig. 7a; 3 is before and 4 is after onset of artificial mixing), confirming the observed regime change in AHM. If sediment-based reduced substances from former higher trophic status 

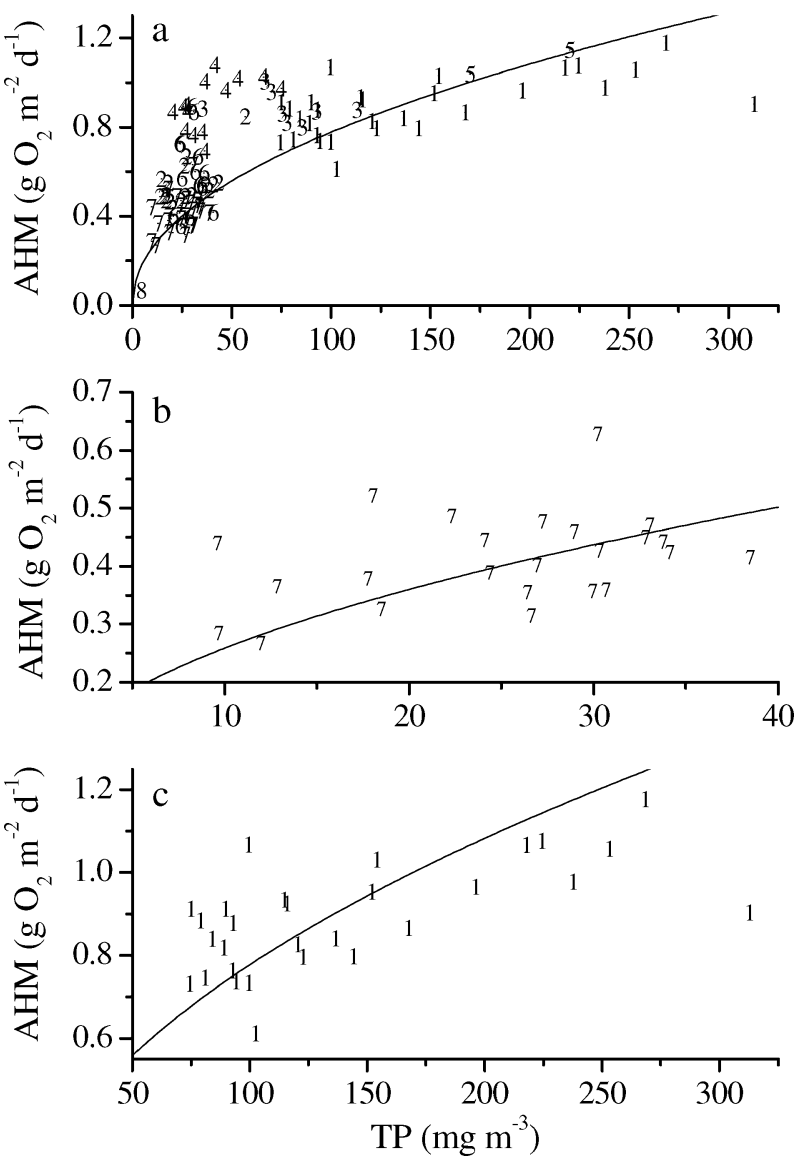

Fig. 7. AHM (equal to AHOD for lakes with oxic hypolimnia) as a function of TP (at the end of winter mixing) in the Swiss Plateau lakes 1, Greifensee (1978-2006, data from Eawag and AWEL); 2, TU (1983-2006, this study); 3, PF (1985-1992, this study); 4, PF with artificial winter mixing (1993-2006, this study); 5, Lake Hallwil (1982 and 1985, Scheidegger et al. 1994); 6, Lake Zurich (1993-2007, data from AWEL); and 7, Lake Lucerne "Kreuztrichter" (1960-1987, data from Eawag); as well as 8, oligotrophic Balkan Lake Ohrid (2001-2004, Matzinger et al. 2006). AHM is shown for lakes 1-5, whereas AHOD was calculated for lakes 6-8 with oxic hypolimnia. The solid line shows empirical AHOD-TP relationship for North American lakes by Chapra and Canale (1991). (a) is an overview of lakes 18; (b) and (c) show data from Lake Lucerne (7) and Greifensee (1), respectively, during oligotrophication. Note the different scales.

played a major role, resilience in AHM would be expected during oligotrophication. Figure $7 b, c$ highlights two lakes for which data during major oligotrophication are available. Whereas Lake Lucerne shifted from mesotrophic to oligotrophic between 1964 and 1987 (Fig. 7b), Greifensee shifted from hypertrophic to eutrophic between 1978 and 2006 (Fig. 7c). For both Lake Lucerne and Greifensee a good correlation was found between TP and AHM, with reasonable agreement with the relationship by Chapra and Canale (1991). Neither case shows a lag of AHM decrease compared to TP reduction, which highlights the importance of current lake productivity. However, detection of a decrease in AHM during oligotrophication may require several years of monitoring, given the scatter of AHM in Figs. 7b,c.

Sediment contribution to AHM-Fluxes of reduced substances from the sediment were estimated in the range of 0.34-0.44 $\mathrm{g} \mathrm{O}_{2} \mathrm{~m}^{-2} \mathrm{~d}^{-1}$. Although the fluxes at the sediment-water interface are expected to be subject to uncertainties from measurements and flux calculation, they are well in line with sediment oxygen uptake (Smith and Matisoff 2008) and $\mathrm{CH}_{4}$ fluxes (Matthews et al. 2005) of other lakes. The contribution of reduced substances from the sediment to total AHM was found to be 42\% (2004-2007) in PF and between 63\% (1994) and 86\% (2004-2007) in TU. These values are in the range of observed sediment contributions to AHOD in other shallow, seasonally stratified lakes (Cornett and Rigler 1987; Gelda et al. 1995) and consistent with $\mathrm{CH}_{4}$ and $\mathrm{NH}_{4}^{+}$sediment contributions observed in a shallow lake by Carignan and Lean (1991).

From this sediment-based contribution $60-80 \%$ stems from the top sediment layers, which were deposited over the last $10 \mathrm{yr}$. Layers older than $10 \mathrm{yr}$ contribute only 20 $43 \%$ to sediment-based AHM, corresponding to $16-18 \%$ of the total AHM. If downward DO flux from the epilimnion is included, contribution of old sediment layers is even slightly smaller, between $15 \%$ and $16 \%$ of total AHM. The layers older than $10 \mathrm{yr}$ include the sediment deposited during the eutrophication period 1960-1980, both for recent measurements as well as for pore-water profiles from the early 1990s. Interestingly, the contribution to the total AHM by sediment layers $>10 \mathrm{yr}$ did not change between the 1990s and 2007.

The importance of sediment-based AHM from both recent and old sediment layers is expected to increase with the ratio of sediment area $A_{\text {hyp }}$ to hypolimnion volume $\mathrm{V}_{\text {hyp }}$ (Rippey and McSorley 2009). $\mathrm{A}_{\text {hyp }}: \mathrm{V}_{\text {hyp }}$ is $\sim 40 \%$ lower in PF than in TU $\left(0.08 \mathrm{~m}^{-1}[\mathrm{PF}]\right.$ vs. $\left.0.14 \mathrm{~m}^{-1}[\mathrm{TU}]\right)$, partly explaining the $\sim 50 \%$ lower relative sediment contribution to AHM (42\% [PF] vs. $86 \%[\mathrm{TU}]) . \mathrm{A}_{\text {hyp }}: \mathrm{V}_{\text {hyp }}$ affects not only the importance of sediment layers but also DO concentration in the hypolimnion, a critical parameter for aquatic organisms. Exposing the hypolimnia $(\mathrm{z}>10 \mathrm{~m})$ of the lakes in Fig. 7 to the sediment-based AHM of $0.44 \mathrm{~g} \mathrm{O}_{2} \mathrm{~m}^{-2} \mathrm{~d}^{-1}$ found for $\mathrm{TU}$ in 2007 would lead to volumetric oxygen depletion over the 8 months of stratification between $0.7 \mathrm{mg} \mathrm{O}_{2} \mathrm{~L}^{-1}$ in Lake Ohrid (average depth $\sim 155 \mathrm{~m}$; Matzinger et al. 2006) and $15 \mathrm{mg} \mathrm{O}_{2} \mathrm{~L}^{-1}$ in TU. If we assume AHM in the water column of $\sim 0.01 \mathrm{~g} \mathrm{O}_{2} \mathrm{~m}^{-3} \mathrm{~d}^{-1}$ (TU, 2004-2006), the sediment would contribute between $86 \%$ (TU) and $23 \%$ (Lake Ohrid) to total AHM. Lakes shallower than TU and $\mathrm{PF}$ are expected to be more affected by sediment-based AHM and would be more strongly influenced by old sediment layers that were potentially deposited under more eutrophic conditions. However, it should be noted that all the above statements do not apply to shallow lakes that remain mostly unstratified because sediment-water exchange in such systems is dominated by sediment resuspension (Kalff 2002) and benthic organisms (Wang et al. 2001). Although there is no lower depth limit for stratification, most temperate lakes with maximal depth of less than 10 
$15 \mathrm{~m}$ occasionally destratify during summer (Kalff 2002; Branco and Torgersen 2009). As a result, the $86 \%$ sediment contribution to AHM found in TU is close to the maximum expected in seasonally stratified lakes. Similarly, the $\sim 15 \%$ contribution to AHM of sediment layers older than 10 $13 \mathrm{yr}$ (which corresponds to a sediment depth of $\sim 5 \mathrm{~cm}$ in TU and PF) is probably in the upper range.

Overall implications of results - Degradation of organic matter during settling through the water column paired with oxidation of reduced substances from the most recent sediment layers (last $10 \mathrm{yr}$ ) contributes $\sim 83 \%$ of AHM for both PF and TU. We conclude that AHM in PF and TU is mainly controlled by the current lake productivity. Nevertheless, old sediment depositions of $>10 \mathrm{yr}$ still have a substantial effect of $\sim 15 \%$ (including downward DO flux from the epilimnion) of total AHM and between $20 \%$ and $43 \%$ of sediment-based AHM. Because most temperate, seasonally stratified lakes are of similar depth or deeper than TU and PF, the above proportions of sediment-based AHM and contributions of old layers are expected to be close to an upper estimate for most lakes.

In terms of lake management, our results imply that artificial oxygenation or aeration systems are not likely to reduce organic matter deposits in the sediment. Given the relatively small contribution of reduced substances to the $\mathrm{O}_{2}$ balance already 5-10 yr after the eutrophic period, dredging of old, organically rich sediment would not reduce AHM significantly. The only efficient long-term measure to reduce summer anoxia and reestablish lake ecosystems is the reduction of anthropogenic nutrient loads or external organic loadings. A similar conclusion was found by Liboriussen et al. (2009) regarding oxygenation to prevent anoxia and concurrent hypolimnetic $\mathrm{NH}_{4}^{+}$accumulation, by Moosmann et al. (2006) and Gächter and Wehrli (1998) regarding oxygenation and artificial mixing to reduce lakeinternal P loading, by Annadotter et al. (1999) regarding sediment dredging to reduce lake-internal P loading, and by Müller and Stadelmann (2004) regarding oxygenation and artificial mixing to improve conditions for egg survival of bottom-spawning fish. Nevertheless, the previously mentioned lake management measures can provide temporary relief from negative effects of anoxia. For instance, oxygenation has been shown to maintain DO thresholds in drinking water reservoirs (Singleton and Little 2006), whereas artificial winter mixing can reduce accumulation of S(-II) (this study).

\section{Acknowledgments}

This work was only possible thanks to the extensive data collection by Amt für Abfall, Wasser, Energie, und Luft (AWEL), financed by the Canton of Zurich. For recent sediment collection and analyses, we thank Ruth Stierli and Alois (Wisi) Zwyssig. Marian Fujak is acknowledged for the dating of the sediments. The analysis profited much from modeling the Pfäffikersee water column stratification performed by John C. Little. We acknowledge the input by Walo Meier, Barbara Känel, and Mike Sturm. We also thank Lee Bryant, Bo Thamdrup, and two anonymous reviewers for constructive comments on an earlier version of this manuscript. The study was financially supported by a grant from AWEL (Cantonal Government of Zurich) and by Eawag.

\section{References}

Aeberli, B., And P. Keller. 1995. Untersuchungen des Sauerstoffhaushaltes und der Sedimente im Türlersee im Hinblick auf die Beurteilung der Auswirkungen der Zirkulationsunterstützung. Report by Univ. of Zurich for the Canton of Zurich (AWEL). Zurich, Switzerland. [Analysis of the oxygen regime and lake sediments in Türlersee to assess effects of artificial lake mixing in winter.]

Annadotter, H., G. Cronberg, R. Aagren, B. Lundstedt, P.-Å. NiLSSON, AND S. STRÖBECK. 1999. Multiple techniques for lake restoration. Hydrobiologia 395/396: 77-85, doi:10.1023/ A:1017011132649

BÉdARd, C., And R. KNOwles. 1991. Hypolimnetic O $\mathrm{O}_{2}$ consumption, denitrification, and methanogenesis in a thermally stratified lake. Can. J. Fish. Aquat. Sci. 48: 1048-1054.

Branco, B. F., And T. Torgersen. 2009. Predicting the onset of thermal stratification in shallow inland waterbodies. Aquat. Sci. 71: 65-79, doi:10.1007/s00027-009-8063-3

Bryant, L. D., C. Lorrai, D. F. McGinnis, A. Brand, A. Wüest, AND J. C. LitTLE. 2010. Variable sediment oxygen uptake in response to dynamic forcing. Limnol. Oceanogr. 55: 950-964.

CARignan, R., AND D. R. S. LeAN. 1991. Regeneration of dissolved substances in seasonally anoxic lake: The relative importance of processes occurring in the water and in the sediments. Limnol. Oceanogr. 36: 683-707, doi:10.4319/1o.1991.36.4.0683

Chapra, S. C. 1997. Surface water quality modelling. McGraw-Hill. , AND R. P. Canale. 1991. Long-term phenomenological model of phosphorous and oxygen in stratified lakes. Water Res. 25: 707-715, doi:10.1016/0043-1354(91)90046-S

Charlton, M. N., J. E. Milne, W. G. Booth, and F. Chiocchio. 1993. Lake Erie offshore in 1990: Restoration and resilience in the central basin. J. Great Lakes Res. 19: 291-309, doi:10.1016/S0380-1330(93)71218-6

Cornett, R. J., And F. H. Rigler. 1987. Decomposition of seston in the hypolimnion. Can. J. Fish. Aquat. Sci. 44: 146-151, doi:10.1139/f87-019

DEW. 2002. Original title in German. Wiley VCH. [German standard methods for the examination of water, wastewater, and sludge.]

Elber, F., J. Hürlimann, And K. Niederberger. 2001a. Entwicklung des Gesamtphosphors im Türlersee anhand der im Sediment eingelagerten Kieselalgen. Report by AquaPlus for the Canton of Zurich (AWEL). [Trends in total phosphorus concentration in Türlersee based on diatoms in the sediments.] _. 2001b. Entwicklung des Gesamtphosphors im Pfäffikersee anhand der im Sediment eingelagerten Kieselalgen. Report by AquaPlus for the Canton of Zurich (AWEL). [Trends in total phosphorus concentration in Pfäffikersee based on diatoms in the sediments.]

EpPing, E. H. G., AND W. Helder. 1997. Oxygen budgets calculated from in situ oxygen microprofiles in Northern Adriatic sediments. Cont. Shelf Res. 17: 1737-1764, doi:10.1016/S0278-4343(97)00039-3

Gächter, R., AND B. Wehrli. 1998. Ten years of artificial mixing and oxygenation: No effect on the internal phosphorus loading of two eutrophic lakes. Environ. Sci. Technol. 32: 3659-3665, doi:10.1021/es9804181

Gantzer, P. A., L. D. Bryant, and J. C. Little. 2009. Effect of hypolimnetic oxygenation on oxygen depletion rates in two water-supply reservoirs. Water Res. 43: 1700-1710, doi:10.1016/j.watres.2008.12.053

Gelda, R. K., M. T. Auer, and S. W. Effler. 1995. Determination of sediment oxygen demand by direct measurements and by inference from reduced species accumulation. Mar. Freshw. Res. 46: 81-88. 
Hupfer, M., And J. Lewandowski. 2008. Oxygen controls the phosphorus release from lake sediments - a long-lasting paradigm in limnology. Int. Rev. Hydrobiol. 93: 415-432, doi:10.1002/iroh.200711054

Hutchinson, G. E. 1938. On the relation between the oxygen deficit and the productivity and the typology of lakes. Int Rev. Gesamt. Hydrobiol. 36: 336-355, doi:10.1002/iroh. 19380360205

KalfF, J. 2002. Limnology: Inland water ecosystems. Prentice Hall.

Larsen, D. P., D. W. Schults, and K. W. Malueg. 1981. Summer internal phosphorus supplies in Shagawa Lake, Minnesota. Limnol. Oceanogr. 26: 740-753, doi:10.4319/ 10.1981.26.4.0740

Li, Y. H., And S. Gregory. 1974. Diffusion of ions in seawater and in deep-sea sediments. Geochim. Cosmochim. Acta 38: 703-714, doi:10.1016/0016-7037(74)90145-8

Liboriussen, L., M. SøndergaArd, E. Jeppesen, I. Thorsgaard, S. Grünfeld, T. S. JaKobsen, ANd K. Hansen. 2009. Effects of hypolimnetic oxygenation on water quality: Results from five Danish lakes. Hydrobiologia 625: 157-172, doi:10.1007/ s10750-009-9705-0

Lorke, A., B. Müller, M. Maerki, And A. Wüest. 2003. Breathing sediments: The control of diffusive transport across the sediment-water interface by periodic boundary-layer turbulence. Limnol. Oceanogr. 48: 2077-2085.

Maerki, M., B. Wehrli, C. Dinkel, And B. Müller. 2004. The influence of tortuosity on molecular diffusion in freshwater sediments of high porosity. Geochim. Cosmochim. Acta 68: 1519-1528, doi:10.1016/j.gca.2003.09.019

Matthews, D. A., And S. W. EfFler. 2006. Long-term changes in the areal hypolimnetic oxygen deficit (AHOD) of Onondaga Lake: Evidence of sediment feedback. Limnol. Oceanogr. 51: 702-714.

, AND C. A. Matthews. 2005. Long-term trends in methane flux from the sediments of Onondaga Lake, NY: Sediment diagenesis and impacts on dissolved oxygen resources. Arch. Hydrobiol. 163: 435-462, doi:10.1127/0003-9136/ 2005/0163-0435

Matzinger, A., Z. Spirkovski, S. Patceva, and A. Wüest. 2006. Sensitivity of ancient Lake Ohrid to local anthropogenic impacts and global warming. J. Great Lakes Res. 32: 158-179, doi:10.3394/0380-1330(2006)32[158:SOALOT]2.0.CO;2

Moosmann, L., R. Gächter, B. Müller, And A. Wüest. 2006. Is phosphorus retention in autochthonous lake sediments controlled by oxygen or phosphorus? Limnol. Oceanogr. 51: 763-771.

Müller, B., Y. Wang, and B. Wehrli. 2006. Cycling of calcite in hard water lakes of different trophic states. Limnol. Oceanogr. 51: 1678-1688.

Müller, R., and P. Stadelmann. 2004. Fish habitat requirements as the basis for rehabilitation of eutrophic lakes by oxygenation. Fish. Manage. Ecol. 11: 251-260, doi:10.1111/ j.1365-2400.2004.00393.x
Niederhauser, P. 1995. Pfäffikersee: Untersuchungen des Seesediments und des Porenwassers im April 1995, Vergleich mit den Untersuchungsresultaten von 1992, 1993 und 1994. Canton of Zurich, AWEL. [Pfäffikersee: Study of lake sediments and sediment porewater in April 1995, comparison with results from 1992, 1993 and 1994.]

— , B. Känel, W. Meier, W. Labhart, K. Nyffenegger, and C. Balsiger. 2006. Wasserqualität der Seen, Fliessgewässer und des Grundwassers im Kanton Zürich - Statusbericht 2006. Canton of Zurich, AWEL. [Water quality of lakes, rivers and groundwater in the canton of Zurich-Status report 2006.]

Rast, W., AND G. F. Lee. 1978. Summary analysis of the North American (US portion) OECD eutrophication project: Nutrient loading-lake response relationships and trophic state indices. EPA-600/3-78-008. U.S. Environmental Protection Agency.

Rippey, B., AND C. McSorley. 2009. Oxygen depletion in lake hypolimnia. Limnol. Oceanogr. 54: 905-916.

Scheidegger, A., A. Stöckli, And A. Wüest. 1994. Einfluss der internen Sanierungsmassnahmen auf den Sauerstoffhaushalt im Hallwilersee. Wasser Energie Luft 5: 126-131. [Impact of lake-internal mitigation measures on oxygen regime of Lake Hallwil.]

Singleton, V. L., And J. C. Little. 2006. Designing hypolimnetic aeration and oxygenation systems - a review. Environ. Sci. Technol. 40: 7512-7520, doi:10.1021/es060069s

Smith, D. A., And G. Matisoff. 2008. Sediment oxygen demand in the central basin of Lake Erie. J. Great Lakes Res. 34: 731-744.

Stumm, W., And J. J. Morgan. 1996. Aquatic chemistry. Wiley Interscience.

Vollenweider, R. A. 1969. Möglichkeiten und Grenzen elementarer Modelle der Stoffbilanz von Seen. Arch. Hydrobiol. 66: 1-36. [Possibilities and limits of elementary models for lake material balances.]

Wang, F., A. Tessier, and L. Hare. 2001. Oxygen measurements in the burrows of freshwater insects. Freshw. Biol. 46: 317-327, doi:10.1046/j.1365-2427.2001.00678.x

Wang, F. Y., And P. M. Chapman. 1999. Biological implications of sulfide in sediment-a review focusing on sediment toxicity. Environ. Toxicol. Chem. 18: 2526-2532, doi:10.1002/ etc. 5620181120
Associate editor: Bo Thamdrup

Received: 12 November 2009 Accepted: 11 May 2010 Amended: 17 June 2010 